\title{
La teología del papa Francisco
}

\author{
José Ignacio González Faus \\ Cristianisme i Justícia \\ Barcelona, España.
}

El libro de Juan Carlos Scannone, S. J., La teología del pueblo. Raíces teológicas del papa Francisco (Sal Terrae, 2017), que se ofrece como un resumen de la teología de Francisco, puede servir al lector para conocer mejor un posible "cisma" en la teología de la liberación, que se evitó gracias a la mesura y al afán de unidad por ambas partes. Es más o menos sabido que, cuando apareció la teología de la liberación, pareció levantarse en Argentina otra corriente llamada "teología del pueblo". ¿Dónde estaban las diferencias?

Caricaturizando un poco, podríamos decir que se distanciaban por una especie de alergia de los argentinos a todo lo que sonara a marxista, quizá porque allí el pueblo era sobre todo peronista -y sin olvidar que el peronismo se llamó en sus orígenes "justicialismo"-, pero con cierto peligro de descuidar los importantes factores económicos de la liberación, atendiendo más a los culturales. Y por el otro lado, una atención demasiado exclusiva al cambio de estructuras sociales, (necesariamente futuro por muy urgente que fuera) con cierto peligro de descuidar la atención al presente. Esto acabaría llevando a la irónica constatación de J. Comblin, poco antes de morir: "nosotros optamos por los pobres y los pobres optaron por las sectas", una frase que se entiende mejor si la parafraseamos más o menos así: "optamos por los pobres del mañana descuidando a los de hoy". Así, la teología del pueblo aparecía como más cultural y más espiritual (menos conflictiva también) y la teología de la liberación como más social y más política (pero más conflictiva). La primera parecía tener más contacto con la realidad de los pobres y la otra más con el estudio de las ciencias sociales.

El tiempo ha ido mostrando que, en realidad, se trataba solo de acentos. Gustavo Gutiérrez dijo ya en su primer libro, considerado como la partida de nacimiento de la teología de la liberación, que esta era una forma de teología espiritual, que no sería auténtica teología de la liberación mientras no la hiciera 
el mismo pueblo y, como cita varias veces Scannone, su siguiente obra (Beber en el propio pozo) es un auténtico tratado de teología espiritual y tradicional. Algo parecido vale de Jon Sobrino, tal como se percibe en la segunda parte de su cristología (recuérdese también su título Liberación con espíritu). Y en otros campos, si la teología de la liberación produjo mártires como Mons. Romero e Ignacio Ellacuría, también en Argentina ha habido mártires, como Mons. Angelelli y el padre Mugica; las comunidades de base, cantadas por L. Boff, tenían mucho de búsqueda de una espiritualidad popular, y creo que la letra de la misa nicaragüense unifica bastantes rasgos de espiritualidad y de liberación, como lo de la tal María que "va a planchar muy humildemente la ropa que goza la mujer hermosa del terrateniente", que contiene tanta o más mariología que todos los dogmas marianos.

Y es que, en realidad, se trataba de dos hermanas, más que de dos adversarias. Por eso es de agradecer que no se enfrentaran y que supieran aparcar las sospechas iniciales, buscando conocerse mejor. Finalmente, en mi opinión al menos, la teología de Francisco ha explicitado mucho más los aspectos socioeconómicos de la teología de la liberación y ha tenido prisa por beatificar a Mons. Romero, creando así una especie de abrazo entre las dos corrientes.

En este contexto se comprenderá más la conveniencia de acercarse a la exposición de Scannone sobre la teología del pueblo, mucho menos conocida en occidente. Quizá porque es una teología "nativa", mientras que algunos de los grandes teólogos de la liberación -Ellacuría, Sobrino, Comblin o Pedro Trigoson europeos y se les veía más por aquí.

La obra de Scannone consta de tres partes: una primera parte histórica sobre la génesis de esa teología del pueblo, a partir sobre todo de Lucio Gera (gran persona, a quien tuve la suerte de conocer personalmente, creo que en Puebla). Otra segunda parte más sistemática y muy centrada en torno a la idea de inculturación, analizando lo popular, lo sapiencial y lo teológico. Y una tercera parte que busca ya exponer al lector la teología de Francisco, derivada de lo dicho en la parte anterior y que es la que me ha gustado más: arrancando de Gaudium et spes, tal como hiciera Medellín, asistimos en Francisco a un proceso de inculturación en lo popular y de mística popular, que se refleja ya en Aparecida y se expresa, sobre todo, en los dos últimos capítulos de la Evangelii gaudium. El aparente eslogan de la teología de la liberación, "los pobres nos evangelizan", se entiende mucho mejor desde esa inculturación de la fe en ellos: "porque la gracia no solo supone la naturaleza, sino la cultura, y se encarna en ella" ( $E G$, 238). Y termina el libro con un capítulo dedicado a los cuatro principios que, según Francisco, ayudan a la construcción de un pueblo: el tiempo es superior al espacio, la unidad prevalece sobre el conflicto, la realidad es más importante que la idea y el todo es superior a las partes. 
Merece destacarse la delicadeza del autor, que procura integrar y no herir a nadie, aunque, ahora en negativo, a ratos da la sensación de cierto temor a recoger aquello que parezca venir del mundo no creyente: como si todo lo bueno hubiera de proceder de la Iglesia y como si el Vaticano II no hubiera reconocido que la Iglesia debe mucho a los de fuera y los necesita también. Queramos o no, Hegel y Marx, con todas sus limitaciones, están ahí; y es imposible pensar en la historia y en la economía sin pasar, de algún modo, por ellos, recordando lo que dijo del primero el nada sospechoso Menéndez y Pelayo: "hasta en sus errores enseña".

Dicho esto, me gustaría terminar esta presentación destacando algunas incomodidades, o mejor, ambigüedades que me suscita la palabra pueblo y que quizá son más debidas a mi contexto geográfico europeo. Otros verán qué vigencia pueden tener en el contexto latinoamericano.

En primer lugar, me siento algo incómodo ante la acepción del pueblo como nación, a la cual Scannone da mucha importancia. Quizás eso valga para Argentina, a cuya historia dedica el autor varias páginas para mostrarlo. Pero en Europa sigue vigente la frase de Pío XI: "la Iglesia ha perdido a la clase obrera". $\mathrm{El}$ pueblo pobre mayoritariamente no es creyente. La mística popular hay que buscarla en magníficos ejemplos minoritarios de la Acción Católica Obrera, pero sin posibilidad de generalizar.

En España, además, la descristianización veloz ha travestido muchos elementos de la religiosidad popular en puramente sociológicos o culturales. Leyendo a Scannone, me preguntaba a veces qué vigencia podrían tener sus observaciones para algunos fenómenos de mi país. Por ejemplo, y sin ánimo de ofender, sino más bien de reflexionar, para nuestra "semana santa andaluza". Me temo que, al menos entre nosotros, lo popular esté mucho más marcado por las dimensiones culturales que acompañan a lo religioso, que por su núcleo específicamente creyente. La inculturación de la fe en lo popular llega ya tarde, en parte por un innegable abandono de los pobres por nuestra Iglesia. Creo también que, en algunos lugares de América Latina, quizá no en Argentina, había una falsa inculturación de la cruz, que ha llevado a muchas mujeres a aceptar un machismo intolerable, del cual se han ido liberando, gracias a la teología de la liberación.

En tercer lugar, al menos aquí, en nuestro occidente, creo que la categoría de pueblo, con todos sus valores, no puede sustituir a la de clase: un africano llegado en patera y un parado español de larga duración tienen entre sí más en común que ese español con los grandes multimillonarios de su mismo país; no en vano España es el país de la Unión Europea donde las diferencias sociales son mayores. Y esto me parece válido para otros lugares de América Latina: un emigrante salvadoreño o guatemalteco o mexicano tienen más comunidad entre ellos de la que pueda tener el primero con una de esas "catorce familias" dueñas del país, o el tercero con todo el clan financiero de Monterrey, por más que su nación sea la misma. La llamada "lucha de clases", mejor hubiera sido decir "agresión de 
clases", no fue un invento de Marx, sino que atraviesa toda la historia humana, ya desde que Aristóteles justificara la esclavitud como conforme a la naturaleza, o Voltaire o Montesquieu la justificaran como necesaria para mantener el precio del cacao...

Finalmente, al menos en este occidente desde el que escribo, queda el problema de la manipulación del pueblo por la intelectualidad reinante y los medios de comunicación social, que acaban siendo creadores de opinión. Y en América Latina habría que tener en cuenta que algunos "maestros de opinión", como Borges, Atahualpa Yupanki o García Márquez, no son precisamente cristianos. Tengo la impresión de que Francisco, en algunos momentos de la Evangelii gaudium, sí que es consciente de ese influjo.

No pretendo que esto sean críticas, sino más bien obstáculos geográficos, algunos creo que bien serios, a tener en cuenta. Si conseguimos evitarlos, entonces será el momento de valorar y aprovechar los muchos temas que giran en torno a esa palabra "pueblo": la inculturación de la fe entre los sencillos, los tesoros todavía no expresados de la espiritualidad de muchos cristianos pobres y la "eminente dignidad de los pobres en la Iglesia" (Bossuet), que se puede expresar con la categoría neotestamentaria y conciliar del pueblo de Dios, donde destaca lo que me parece más querido de Francisco y una de sus mayores aportaciones: el tema, y el valor, de la unidad en la diversidad. De ahí su preferencia por la imagen del poliedro, en vez de la circunferencia (más uniformadora), como señala varias veces Scannone.

Resumiendo lo que he querido decir con estos comentarios: este libro no es para que asimilemos todos sus contenidos, eso podría ser una falta de inculturación, sino su metodología. Pues, como dice la última frase del libro: "Bergoglio no es sólo 'el papa del pueblo' (del pueblo fiel de Dios y de los pueblos), sino también el papa "del discernimiento de los signos de los tiempos"' (p. 274). 